\title{
The influence of the forest on night-time snow surface temperature
}

\author{
Peter Höller \\ Institute for Avalanche Research, Federal Forest Research Centre, Hofburg-Rennweg 1, A-6020 Innsbruck, Austria
}

\begin{abstract}
Snow surface temperature $\left(T_{\mathrm{S}}\right)$ plays an important role in the formation of surface hoar or near-surface faceted crystals. The goal of this study was to obtain detailed information on $T_{\mathrm{s}}$ in different forest stands near the timberline. The investigations were conducted during clear nights and showed that the snow surface temperature is influenced very strongly by the forest canopy. While the air temperature was very similar on the different experimental sites, $T_{\mathrm{s}}$ was higher in the forest than in the open field; on the south-facing slope the difference between the forest and the open field was $3-4.5^{\circ} \mathrm{C}$, and on the north-facing slope approximately $3-7^{\circ} \mathrm{C}$. Taking into account that $\varepsilon_{\text {air }}$ is 0.7 and $\varepsilon_{\text {tree }}$ is 0.94 , the incoming radiation $(I \downarrow)$ for the different experimental sites was calculated by the equation of Brunt (the canopy density was estimated using photographs taken with an $8 \mathrm{~mm}$ fish-eye). To calculate $T_{\mathrm{s}}$, air temperature and averaged values of the net radiation (because the net radiation $(I)$ has only a small range of variation during clear nights) were used. The results show that the calculated values were higher than the measured values (by approximately $2^{\circ} \mathrm{C}$ ). However, a better correlation was found by using lower values of the emissivity $\left(\varepsilon_{\text {air }} 0.67\right.$ and $\left.\varepsilon_{\text {tree }} 0.91\right)$.
\end{abstract}

\section{INTRODUCTION}

Snow surface temperature $\left(T_{\mathrm{s}}\right)$ plays an important role in the formation of surface hoar or near-surface faceted crystals. As shown by Höller (1998), a very simple condition for surfacehoar growth is given if $T_{\mathrm{s}}$ falls below the dew point. More detailed information can be obtained by calculating the difference of water-vapor pressure $(\Delta P)$ between air and snow surface; for example, Hachikubo and Akitaya (1997) used $\Delta P$ to calculate the water-vapor flux (condensation rates). Gubler (1998) developed an empirical formula to estimate the onset of surface hoar and used $T_{\text {air }}$ and $T_{\mathrm{s}}$. Birkeland and others (1998) calculated the vapor-pressure gradient in the uppermost layer of the snowpack; they found values exceeding $-25 \mathrm{hPa} \mathrm{m}^{-1}$ during the night, and these extreme vapor-pressure gradients led to the formation of near-surface faceted crystals.

However, data on snow surface temperature are necessary for the different calculations, both for open sites and for different locations of forest stands. Results on measured snow-temperature profiles in forest stands can be found in Gubler and Rychetnik (1991), but they did not measure snow surface temperature. Thus the main objective of the study was to measure $T_{\mathrm{s}}$ at different forest sites in order to find out how the forest (with different crown closures) influences $T_{\mathrm{S}}$ during night-time. The second objective was to develop a simple formula that makes it possible to calculate $T_{\mathrm{s}}$ using air temperature $\left(T_{\text {air }}\right)$ only.

\section{STUDY AREA AND METHODS OF MEASUREMENTS}

Two different experimental sites were selected in the western part of the Tyrol, Austria. Site A was about $35 \mathrm{~km}$ from Innsbruck (in the Stubai valley) in and beside a larch stand (larix decidua) near the timberline at about $1900 \mathrm{~m}$ a.s.l. $\left(47^{\circ} 7^{\prime} 30^{\prime \prime} \mathrm{N}\right.$, $11^{\circ} 17^{\prime} 50^{\prime \prime} \mathrm{E}$ ); larch trees grow up to $>2000 \mathrm{~m}$ a.s.l. (timberline) and are the only conifer species that lose their needles in winter. Three different measuring zones (open field (Al), clearing (A2) and forest (A3)) were selected. Al was outside the forest on a south-southeast-facing slope (inclination $30^{\circ}$ ) and not influenced by the forest canopy; A2 was a clearing (aspect: south-southeast; slope angle $25^{\circ}$ ) with a diameter of approximately $7 \mathrm{~m} \times 7 \mathrm{~m}$ (about $20 \%$ of the sky was covered by trees); A3 was in the forest (same aspect and slope angle as Al) with touching crowns.

Site B was in the Kühtai in a stone pine stand (pinus cembra) at about $1950 \mathrm{~m}$ a.s.l. $\left(47^{\circ} 12^{\prime} 38^{\prime \prime} \mathrm{N}, 11^{\circ} 05^{\prime} 18^{\prime \prime} \mathrm{E}\right)$; stone pine trees can be seen especially in the central part of the Alps, and grow up to more than $2200 \mathrm{~m}$ a.s.l. Three different measuring zones were selected. Bl was in a great clearing (diameter: $15 \mathrm{~m} \times 15 \mathrm{~m}$ ) on a north-facing slope (inclination $30^{\circ}$ ); B2 was a smaller clearing (same aspect and slope angle as $\mathrm{Bl}$ ) with a diameter of approximately $10 \mathrm{~m} \times 15 \mathrm{~m}$; B3 was in the forest (aspect: north; slope angle $25^{\circ}$ ) with touching crowns (about $75 \%$ of the sky was covered by the forest canopy). The crown closure of all measuring positions was recorded with an $8 \mathrm{~mm}$ fish-eye lens (Fig. 1). To estimate the canopy density ( $x$ in Equations (2), (3) and (6)) for the different locations a so-called Horizontoscope was used. This simple device consists of a glass dome with a compass needle and a bubble level. If a sun chart is mounted on the lower side of the Horizontoscope, the canopy density can be estimated by tracing the line which is reflected by all obstacles (e.g. trees) at the site; these readings were taken in February 1999.

The measurements included air temperature $(2 \mathrm{~m})$, humidity and temperature at $0.1 \mathrm{~m}$ above snow surface at Al. Snow surface temperature and net radiation (incoming minus outgoing) were measured in all three zones of site A; 




a

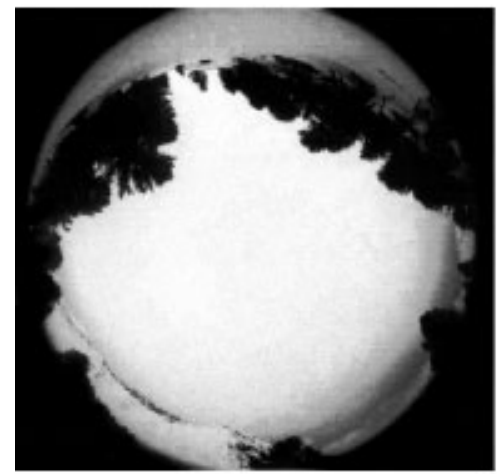

c

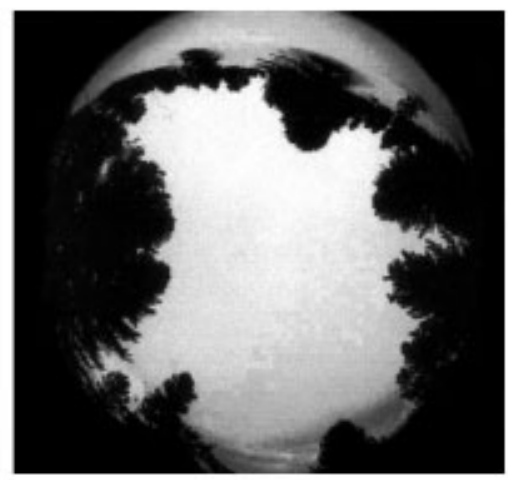

d

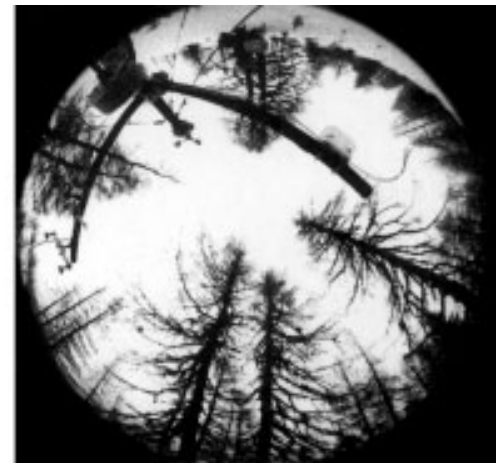

b

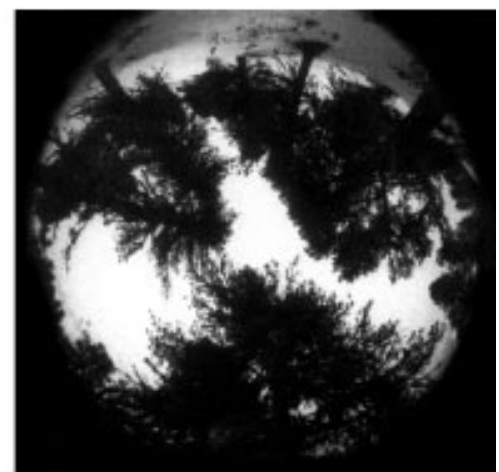

e

Fig. 1. Crown closure of the different measuring locations. (a) A2: clearing in the larch stand ( $x=0.2)$; (b) A3: larch stand $(x=0.6) ;(c)$ B1: great clearing in the stone pine forest $(x=0.1) ;(d)$ B2: small clearing in the stone pine forest $(x=0.3) ;(e)$ B3: stone pine forest $(x=0.75)$.

separate measurements of incoming and outgoing longwave radiation were also performed at $\mathrm{A} 1$ and $\mathrm{A} 3$.

At site $\mathrm{B}$ the temperature at $0.1 \mathrm{~m}$ above snow surface and the snow surface temperature was measured in all three zones. Values of air temperature $(2 \mathrm{~m})$, humidity and net radiation were taken from the meteorological observation site Längental (altitude $1920 \mathrm{~m}$; aspect: northwest; inclination $15^{\circ}$ ) which is approximately $250 \mathrm{~m}$ from site $\mathrm{B}$.

Temperature measurements (snow surface and $0.1 \mathrm{~m}$ above snow surface) were performed with platinum-resistance sensors. The sensors for measuring $T_{\mathrm{s}}$ were placed directly on the snow surface, which was possible during the night because shortwave radiation did not have to be considered (infrared thermometers would have been a good alternative, but they could not be used in this study because of their high cost). Air-temperature and humidity sensors (VAISALA) were placed within a radiation shield. Net radiation (A1, A2 and A3) was measured with three net radiometers (SCHENK). Incoming and outgoing longwave radiation (Al and A3) was measured with two Pyrradiometers (SCHENK).

\section{RESULTS}

The measurements were performed on clear nights in January 1999, with some additional data from previous years. The results of the air-temperature measurements were as expected: higher values at site $\mathrm{A}$, lower values at site $\mathrm{B}$ (Fig. 2). This can be explained by the different locations of the two experimental sites. While site B (stone pine stand) is near to a north-facing plateau where the cold air flows down and forms an inversion layer, site A (larch stand) was on a south-facing slope with more solar absorption.

Investigations by Aulitzky and Turner (1982) showed
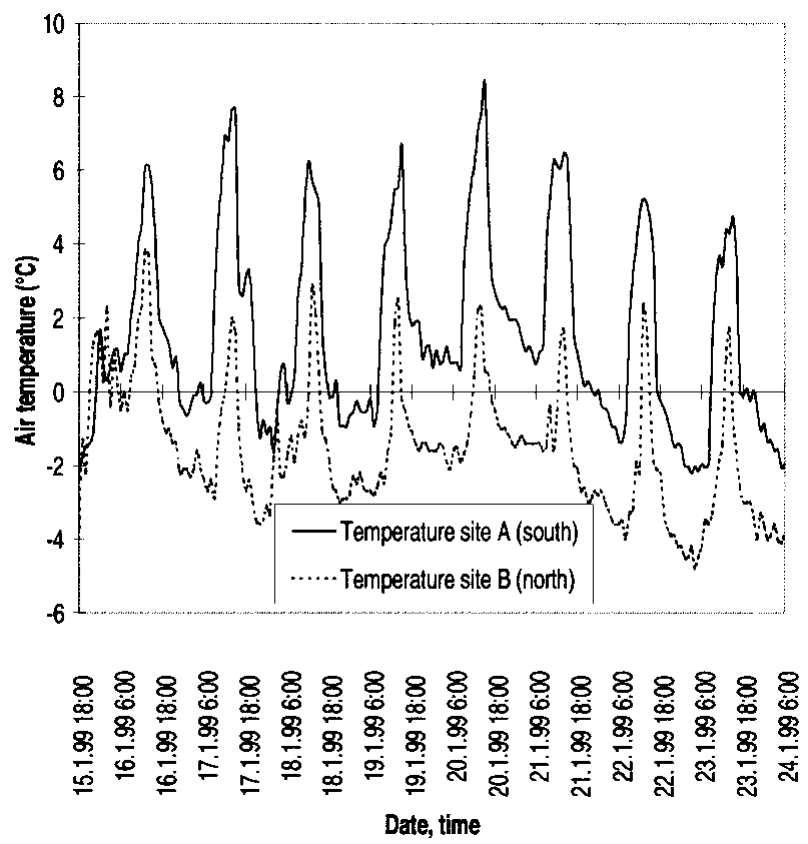

Fig. 2. Air temperature (at $2 \mathrm{~m}$ ) at site $A$ (larch stand on a south-facing slope) and site $B$ (stone pine forest on a northfacing slope), 15-24 January 1999. 

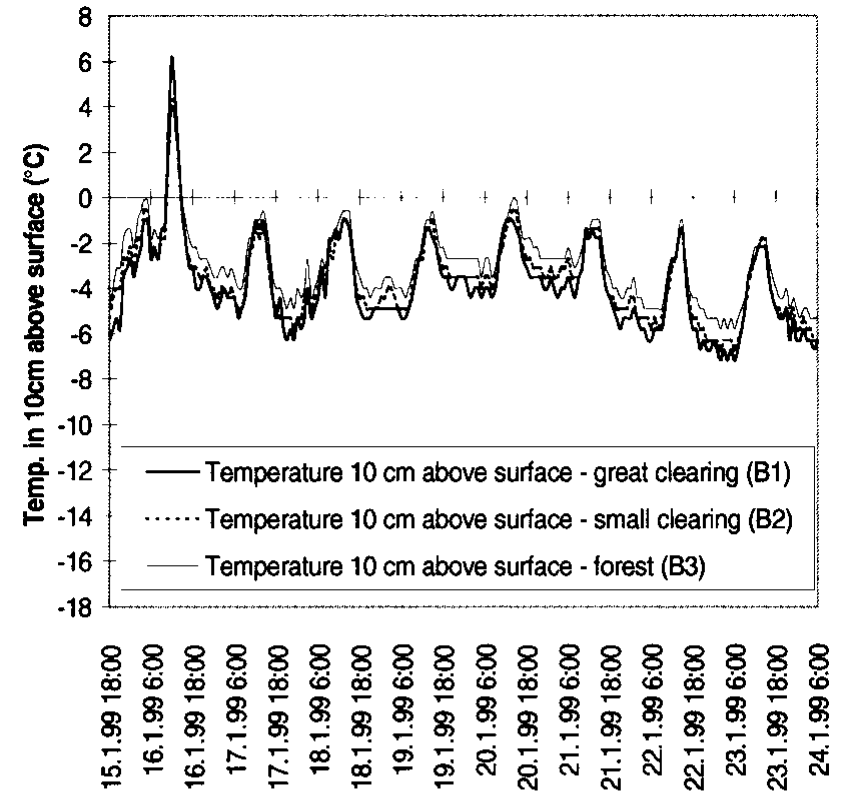

a

Date, time
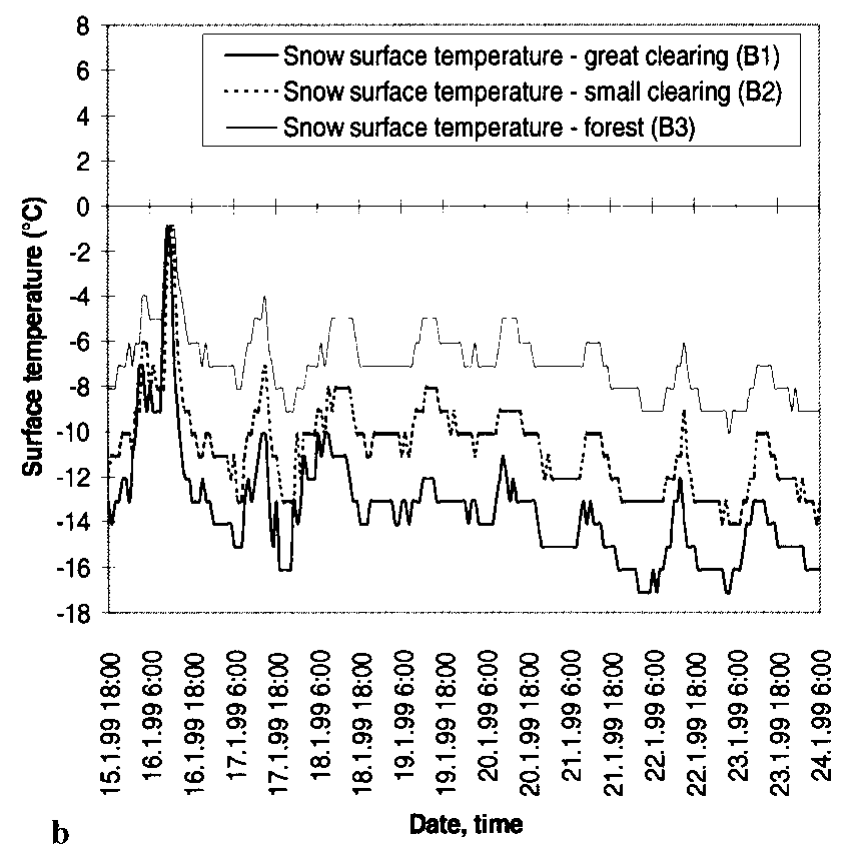

Fig. 3. Temperature at $0.1 \mathrm{~m}$ above snow surface $(a)$ and snow surface temperature $(b)$ at different measuring locations at site B, 15-24 January 1999.

that forest stands in the subalpine region do not have much influence on the air temperature, on either the south- or north-facing slope; the air temperature was almost the same in all zones (open field, forest, opening). These results correspond with data from Höller (1998). Even at $0.1 \mathrm{~m}$ above the snow surface the temperatures were similar at all measuring positions (Fig. 3).

However, a strong temperature gradient was found between the measuring levels 2 and $0.1 \mathrm{~m}$ above the snow surface. During clear nights the air temperature at $2 \mathrm{~m}$ was $2.6^{\circ} \mathrm{C}$ higher (average) than at $0.1 \mathrm{~m}$ above the snow surface. While the temperature at $0.1 \mathrm{~m}$ on the north-facing slope (site B) was lower during day and night (Fig. 4), a change in temperature was found on the south-facing slope (site A), giving higher values at $0.1 \mathrm{~m}$ during daytime (due to higher values of shortwave radiation on the south-facing slope).

As expected, the snow surface temperatures were strongly
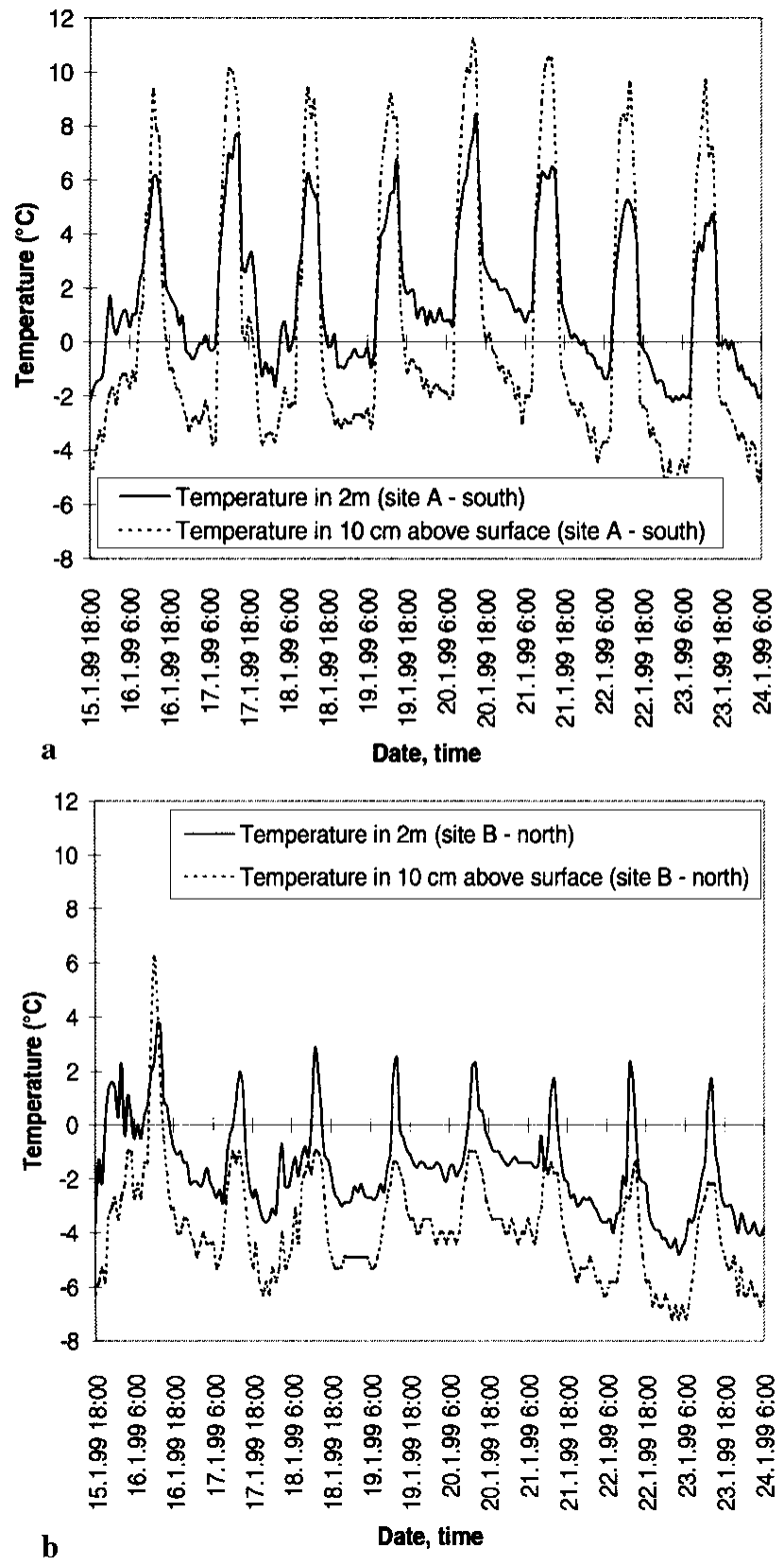

Fig. 4. Temperature at 2 and $0.1 \mathrm{~m}$ above the snow surface in the open field of site $A$ (larch stand on a south-facing slope) (a) and site B (stone pine forest on a north-facing slope) (b).

influenced by the forest canopy. Figure $3 \mathrm{~b}$ shows the snow surface temperatures at site B (continuous time series, 15-24 January 1999). $T_{\mathrm{S}}$ is warmer in the forest than in the great clearing during day and night. Due to the location of site $B$ (a north-facing plateau where cold air flows down and forms an inversion layer), the surface temperature of the great clearing (Bl) was low throughout the day and did not even reach the values of the forest (B3) during daytime. A strong increase of the snow surface temperature at Bl was observed only on 16 January 1999 (because of high air temperatures). At that time $T_{\mathrm{S}}$ at $\mathrm{B}$ l was about the same as at $\mathrm{B}$.

However, during clear nights $T_{\mathrm{s}}$ showed significant differences between the forest and the open field. At site A (south-facing slope) the minimum difference was $3{ }^{\circ} \mathrm{C}$, and the maximum difference $4.5^{\circ} \mathrm{C}$. At site $\mathrm{B}$ (north-facing slope) the corresponding values are $3^{\circ}$ and $7^{\circ} \mathrm{C}$.

As an example, the clear night of 21-22 January is described (Fig. 5). On the south-facing slope (site A) the following values 

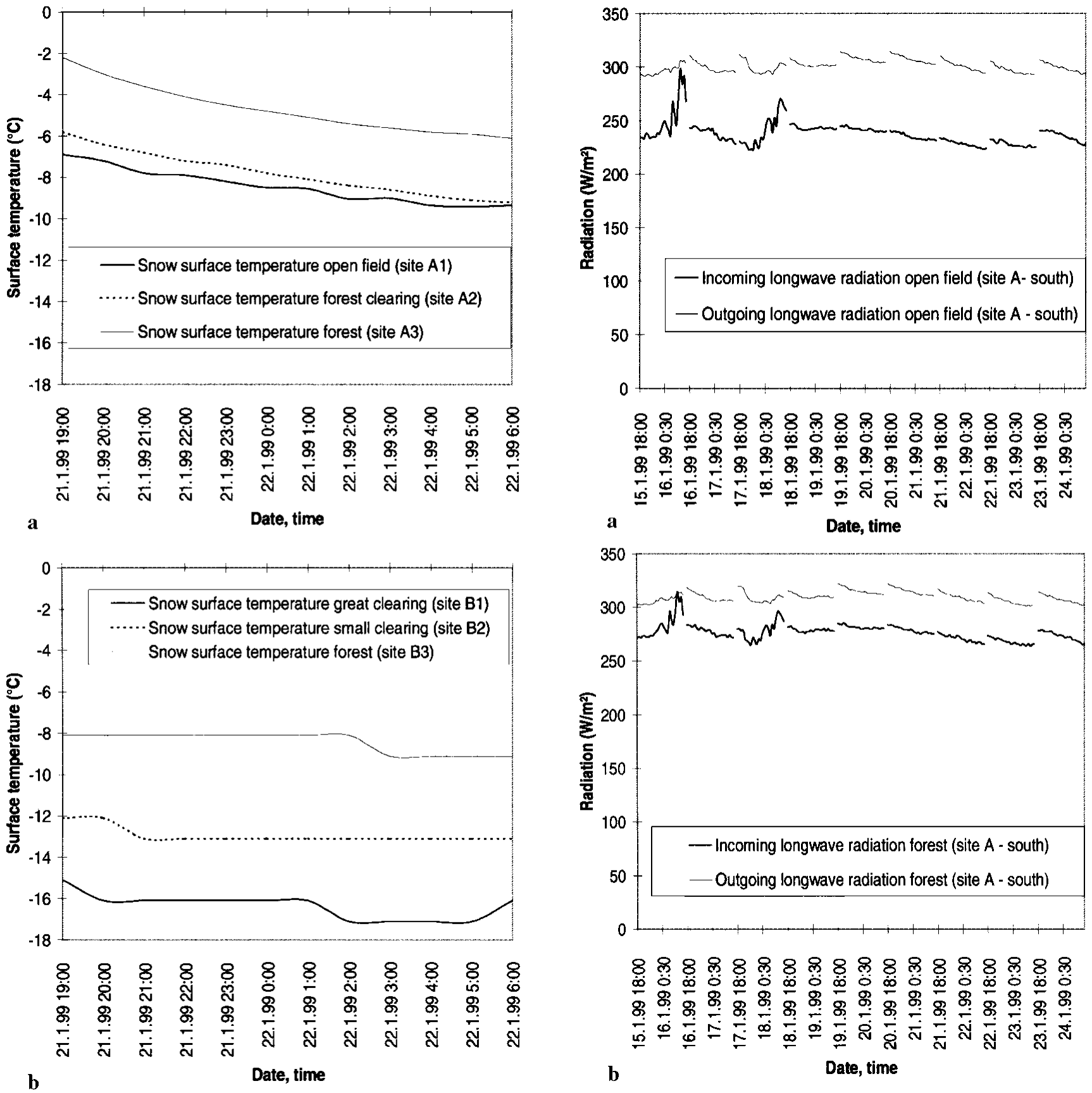

Fig. 5. Snow surface temperature at different measuring locations of site A ( a) and site B (b), 21-22 January 1999.

were measured: open field $(\mathrm{Al})-6.8^{\circ}$ to $-9.6^{\circ} \mathrm{C}$; clearing (A2) $-5.9^{\circ}$ to $-9.5^{\circ} \mathrm{C}$; and forest $(\mathrm{A} 3)-2.2^{\circ}$ to $-6.1^{\circ} \mathrm{C}$. At site $\mathrm{B}$ (north-facing slope) all the corresponding values were lower: great clearing $(\mathrm{Bl})-15^{\circ}$ to $-17^{\circ} \mathrm{C}$; clearing $(\mathrm{B} 2)-12^{\circ}$ to $-13{ }^{\circ} \mathrm{C}$; and forest $(\mathrm{B} 3)-8^{\circ}$ to $-9^{\circ} \mathrm{C}$. Although the stone pine forest on the north-facing slope (site $\mathrm{B}$ ) was much denser than the larch stand on the south-facing slope (site A), $T_{\mathrm{s}}$ was higher inside the low-density larch stand. Moreover, the snow surface temperature in the great clearing of site B (north) was significantly lower than in the open field of site A (south). It can be assumed that the snow surface temperatures on site B (small north-facing slope near to a plateau with a cold climate) are influenced by developing inversion layers which lead to low surface temperatures in all three zones.

Snow surface temperatures at site A (south) were relatively high at the beginning of the night and decreased later on, while the corresponding values at site $\mathrm{B}$ (north) remained

more or less constant. This can be explained by the fact that on the south-facing slope the snow surface temperature increases during daytime (solar absorption), while at site B (north) $T_{\mathrm{s}}$ is not influenced by shortwave radiation.

Incoming and outgoing longwave radiation were measured at Al and A3 (Fig. 6). On the clear nights of 15-24 January the incoming longwave radiation $(I \downarrow)$ was 220$300 \mathrm{~W} \mathrm{~m}^{-2}$ in the open field ( $\left.\mathrm{Al}\right)$ and $260-315 \mathrm{~W} \mathrm{~m}^{-2}$ in the larch stand (A3); outgoing longwave radiation $(I \uparrow)$ was 290-315 $\mathrm{W} \mathrm{m}^{-2}$ at $\mathrm{Al}$ and $300-320 \mathrm{~W} \mathrm{~m}^{-2}$ at A3. While the outgoing longwave radiation in the open field is only 6$11 \mathrm{~W} \mathrm{~m}^{-2}$ lower than in the forest, the incoming longwave radiation in the forest is significantly higher (about 17$50 \mathrm{~W} \mathrm{~m}^{-2}$ ) than in the open field. This can be explained by the additional longwave radiation of the trees. Consequently the net radiation in the forest was always higher than in the open field (see below). 
Table 1. Minimum and maximum net radiation $\left(\mathrm{Wm}^{-2}\right)$ during clear nights for site A (data were calculated from 44 clear nights)

\begin{tabular}{llll}
\hline & Open field & Forest clearing & Larch stand \\
\hline Min. & -67.2 & -60.8 & -36.7 \\
Max. & -57.8 & -50.2 & -31.2 \\
\hline
\end{tabular}

However, net radiation $(I)$ during clear nights has only a small range of variation; net radiation measurements at site $\mathrm{A}$ showed that the difference between maximum and minimum values does not exceed $10 \mathrm{~W} \mathrm{~m}^{-2}$ (Table 1). As shown in Table 1 (data are calculated from 44 clear nights), the net radiation in the open field $(\mathrm{Al})$ is very similar to $I$ inside the clearing (A2), but the longwave balance in the forest (A3) was about $30 \mathrm{~W} \mathrm{~m}^{-2}$ higher than in the open field.

To calculate the incoming longwave radiation $(I \downarrow)$ the following equation was used (Oke, 1987), which is valid for clear-sky and unforested conditions:

$$
I \downarrow=\sigma T^{4} \varepsilon_{\text {air }},
$$

where $\sigma$ is the Stefan-Boltzmann constant $\left(5.67 \times 10^{-8} \mathrm{~W} \mathrm{~m}^{-2}\right)$, $T$ is the temperature in $\mathrm{K}$ and $\varepsilon_{\text {air }}$ is the emissivity of air.

Bader and Weilenmann (1992) used the following equation to calculate $I \downarrow$ inside the forest (clear sky above the forest):

$$
I \downarrow=(1-x) \varepsilon_{\text {air }} \sigma T^{4}+x \varepsilon_{\text {tree }} \sigma T_{\text {tree }}{ }^{4},
$$

where the first part is the incoming radiation of the atmosphere and the second part is the longwave radiation of the trees. $x$ depends on the canopy density (e.g. $x=0$ means no covering by the forest canopy). $\varepsilon_{\text {tree }}$ is the emissivity of the trees; $T_{\text {tree }}$ is the temperature of the needles in $\mathrm{K}$. Following Bader and Weilenmann (1992), $T_{\text {tree }}$ can be set to $T_{\mathrm{s}}$ (snow surface temperature) if trees are covered with snow, or it can otherwise be set to $T$ (air temperature).

Using $T$ instead of $T_{\text {tree }}$ (there was no snow on the crowns during the January 1999 measurements), Equation (3) can be modified:

$$
I \downarrow=\sigma T^{4}\left[(1-x) \varepsilon_{\text {air }}+x \varepsilon_{\text {tree }}\right] .
$$

As the radiation balance $(I)$ during the night includes only longwave parts, the following equation can be used to calculate the outgoing longwave radiation $(I \uparrow)$ :

$$
I \uparrow=I \downarrow-I,
$$

and the outgoing radiation $(I \uparrow)$ is given by the StefanBoltzmann law:

$$
I \uparrow=\sigma T_{\mathrm{s}}^{4} \varepsilon_{\mathrm{s}},
$$

where $T_{\mathrm{S}}$ is the snow surface temperature and $\varepsilon_{\mathrm{S}}$ is the emissivity of snow. Combining Equations (3-5) and taking into account that $\varepsilon_{\mathrm{S}}$ is $1, T_{\mathrm{S}}$ can be calculated:

$$
T_{\mathrm{s}}=\left(\left\{T^{4}\left[(1-x) \varepsilon_{\text {air }}+x \varepsilon_{\text {tree }}\right]\right\}-(I / \sigma)\right)^{0.25} .
$$

Using Equation (6), $T_{\mathrm{s}}$ was calculated for all measurement positions. $x$ was estimated by the measurements with the Horizontoscope (see above); the following values were obtained: A1: 0; A2: 0.2; A3: 0.6; B1: 0.1; B2: 0.3; B3: 0.75 .

The emissivity of air $\left(\varepsilon_{\text {air }}\right)$ was calculated by the equation of Brunt. Taking into account that the average vapor pressure in the observation period was about $3 \mathrm{hPa}$ (this value was cal-

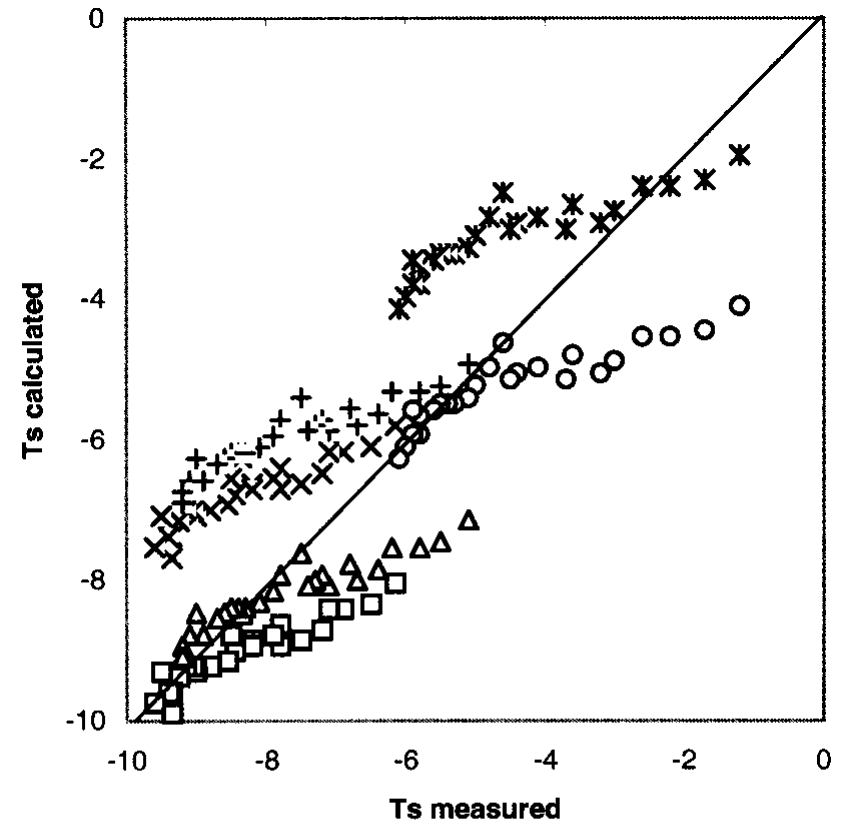
XTs calc. (eair $=0.7) \cdot$ site $A 1$
口Ts calc. (eair=0.67) - site A1
+ Ts calc. (eair $=0,7$; etree $=0,94$ ) - site A2
$\Delta$ Ts calc. (eair $=0,67$; etree $=0,91$ ) - site $A 2$
XTs calc. (eair $=0,7$; etree $=0,94$ ) - site A3
OTs calc. (eair=0,67; etree $=0,91)$ - site A3

Fig. 7. Measured vs calculated values of snow surface temperature at different measuring locations of site A, 21-22 January 1999.

culated from humidity and air-temperature measurements at both experimental sites), $\varepsilon_{\text {air }}$ can be set to 0.7 . The emissivity of the leaves or needles $\left(\varepsilon_{\text {tree }}\right)$ is $0.97-0.98$ (Sellers, 1965; Oke, 1987). In accordance with Gubler and Rychetnik (1991), a value of 0.94 was used (because of a partial view to the clear sky).

Because the difference between maximum and minimum values of the net radiation was relatively small $\left(10 \mathrm{~W} \mathrm{~m}^{-2}\right)$, it should be possible to take averaged values of $I$. The following values were used for site $\mathrm{A}$ (calculated from the net radiation measurements; see Table 1): open field: $-65 \mathrm{~W} \mathrm{~m}^{-2}$; clearing: $-56 \mathrm{~W} \mathrm{~m}^{-2}$; forest: $-34 \mathrm{~W} \mathrm{~m}^{-2}$. The values for site B were estimated from data of the observation site Längental and some additional measurements which were performed in January 2000 (I also took into account that the loss of heat at site B is less than at site $\mathrm{A})$ : great clearing: $-45 \mathrm{~W} \mathrm{~m}^{-2}$; small clearing: $-40 \mathrm{~W} \mathrm{~m}^{-2}$; forest: $-25 \mathrm{~W} \mathrm{~m}^{-2}$.

Figures 7 and 8 show the measured and calculated values of some clear nights in January 1999 at sites A and B, respectively. The measured values at all sites regularly were less than the calculated values (by approximately $2-3^{\circ} \mathrm{C}$ ). The correlation coefficient at site A was between 0.90 (forest) and 0.93 (clearing), and at site B between 0.73 (clearing) and 0.87 (forest).

To obtain a better correlation, however, the values of $\varepsilon_{\text {air }}$ and $\varepsilon_{\text {tree }}$ had to be reduced. To calculate $\varepsilon_{\text {air }}$, the formulations of Brutsaert (1975), Satterlund (1979) and Idso (1981) were used (with regard to the following data: air temperature $-3{ }^{\circ} \mathrm{C}$; vapor pressure $3 \mathrm{hPa}$ ). The Idso formula gives an atmospheric emissivity of $>0.7$. The results of the Satterlund equation 


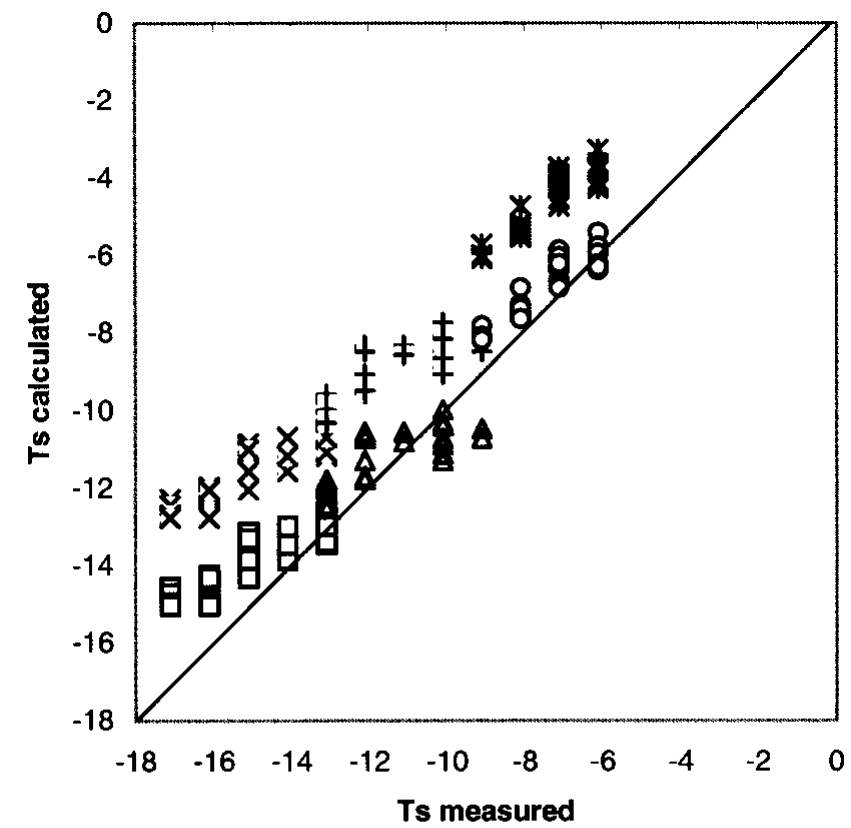

$X$ Ts calc. (eair $=0.7$ ) - site $B 1$

口Ts calc. (eair=0.67) - site B1

+ Ts calc. (eair $=0.7$; etree $=0.94$ ) - site $B 2$

$\Delta$ Ts calc. (eair $=0.67$; etree $=0.91$ ) - site $B 2$

X Ts calc. (eair=0.7; etree $=0.94$ ) - site B3

OTs calc. (eair $=0,67$; etree $=0,91$ ) - site $B 3$

Fig. 8. Measured vs calculated values of snow surface temperature at different measuring locations of site B, 19-22 January 1999.

(suitable for temperatures of $<0^{\circ} \mathrm{C}$ ) were relatively close to the values from Idso. Only the Brutsaert formulation shows emissivities of $<0.7$. Using $3 \mathrm{hPa}$ for the vapor pressure, the atmospheric emissivity is 0.67 .

The emissivity of the trees $\left(\varepsilon_{\text {tree }}\right)$ was reduced in the same way. As published by Sellers (1965), values of about 0.90-0.91 can be applied to pine forests. Although only site B was situated in a stone pine stand, the value of 0.91 was used at site $\mathrm{A}$ (larch stand) too, since larch trees lose their needles in winter, increasing the partial view to the clear sky.

Calculations with the reduced emissivity values $\left(\varepsilon_{\text {air }}=\right.$ 0.67 and $\left.\varepsilon_{\text {tree }}=0.91\right)$ can be found in Figures 7 and 8 for sites $\mathrm{A}$ and $\mathrm{B}$, respectively. These values come closer to the $1: 1$ line, while the correlation coefficients retain their positions. In any case it should be possible to improve the calculations by using lower values of $\varepsilon_{\text {air }}$ and $\varepsilon_{\text {tree. }}$.

\section{GONGLUSION}

The investigations showed that the snow surface temperatures were strongly influenced by the forest canopy. While the temperatures $0.1 \mathrm{~m}$ above the snow surface were similar at all measuring positions, $T_{\mathrm{s}}$ was significantly higher in the forest than in the open field.

During clear nights the snow surface temperature was about $3-4.5^{\circ} \mathrm{C}$ higher in the larch stand (A3) than in the open field (Al). Snow surface temperatures were $3-7^{\circ} \mathrm{C}$ higher in the stone pine forest (B3) than in the great clearing (B1). The canopy of the dense forest (stone pine) prevents cooling of the snow surface (due to longwave radiation) more than does the larch stand.

However, the measured values of the snow surface temperature at site B (stone pine forest on the north-facing slope) were lower than at site A (larch stand on the southfacing slope), although the stone pine forest was much denser than the larch stand. This can be explained by the location of the two different sites. While site B is near to a plateau where cold air flows down and forms an inversion layer, site A was situated on a south-facing slope.

The surface temperatures at site A are relatively high at the beginning of the night, decreasing later on, while the corresponding values at site $\mathbf{B}$ (north) remain more or less constant. It can be assumed that on the south-facing slope the snow surface temperature increases during daytime (solar absorption), while at site $\mathrm{B}$ (north) $T_{\mathrm{s}}$ is not influenced by shortwave radiation.

A simple formula was developed to calculate the snow surface temperature using air temperature $\left(T_{\text {air }}\right)$ and averaged values of $I$ (taking into account that the emissivity of air is 0.7 and the emissivity of the trees is 0.94 ). The calculations showed that the measured values were less than the calculated values (by about $2-3^{\circ} \mathrm{C}$ ). To obtain a better correlation, the values of $\varepsilon_{\text {air }}$ and $\varepsilon_{\text {tree }}$ were reduced to 0.67 and 0.91 , respectively. In that case the values come closer to the $1: 1$ line, so the calculations can be improved by using lower values of the emissivity.

\section{ACKNOWLEDGEMENTS}

I am grateful to A. Klebelsberg of the Tyrolean Hydro Power Company (TIWAG) for supplying the meteorological and nivological data from the observation site in the Kühtai.

\section{REFERENGES}

Aulitzky, H. and H. Turner. 1982. Bioklimatische Grundlagen einer standortsgemässen Bewirtschaftung des subalpinen Lärchen-Arvenwaldes. Mitt. Eidg. Anst. Forstl. Versuchswes., 58(4), 327-580.

Bader, H.-P. and P. Weilenmann. 1992. Modeling temperature distribution, energy and mass flow in a (phase-changing) snowpack. I. Model and case studies. Cold Reg. Sci. Technol., 20(2), 157-181.

Birkeland, K.W., R. F. Johnson and D. S. Schmidt. 1998. Near-surface faceted crystals formed by diurnal recrystallization: a case study of weak layer formation in the mountain snowpack and its contribution to snow avalanches. Arct. Alp. Res., 30(2), 200-204.

Brutsaert, W. 1975. On a derivable formula for long-wave radiation from clear skies. Water Resour. Res., 11(5), 742-744.

Gubler, H. 1998. A model to determine snow surface properties from remote measurements. In ISSW'98. International Snow Science Workshop, 27 September1 October 1998, Sunriver, Oregon. Proceedings. Seattle, WA, Washington State Department of Transportation, 35-48.

Gubler, H. and J. Rychetnik. 1991. Effects of forests near the timberline on avalanche formation. International Association of Hydrological Sciences Publication 205 (Symposium at Vienna 1991 - Snow, Hydrology and Forests in High Alpine Areas), 19-38.

Hachikubo, A. and E. Akitaya. 1997. Effect of wind on surface hoar growth on snow. 7. Geophys. Res., 102(D4), 4367-4373.

Höller, P. 1998. Tentative investigations on surface hoar in mountain forests. Ann. Glaciol., 26, 31-34.

Idso, S. B. 1981. A set of equations for full spectrum and $8-14 \mu \mathrm{m}$ and $10.5-12.5 \mu \mathrm{m}$ thermal radiation from cloudless skies. Water Resour. Res., $17(2), 295-304$.

Oke, T. R. 1987. Boundary layer climates. Second edition. London, Methuen; New York, Routledge Press.

Satterlund, D. R. 1979. An improved equation for estimating long-wave radiation from the atmosphere. Water Resour. Res., 15(6), 1649-1650.

Sellers, W. D. 1965. Physical climatology. Chicago and London, University of Chicago Press. 